\title{
LACTATE DEHYDROGENASE PATTERN IN TISSUES OF PIGS EXPOSED TO ARSENIC AND CADMIUM - A PILOT STUDY
}

\author{
J. ŠALPLACHTA ${ }^{1}$, A. VINKLER ${ }^{2}$
}

${ }^{1}$ Department of Biochemistry, Faculty of Veterinary Hygiene and Ecology, ${ }^{2}$ Department of Animal Reproduction, Faculty of Veterinary Medicine, University of Veterinary and Pharmaceutical Sciences, Brno, Czech Republic

Received May 14, 2001

Accepted August 28, 2001

\section{Abstract}

Šalplachta J., Vinkler, A.: Lactate Dehydrogenase Pattern in Tissues of Pigs Exposed to Arsenic and Cadmium. Acta Vet. Brno 2001, 70: 285-290.

The aim of this study was to compare the sensitivity of various tissues of young pigs (Large White) chronically exposed to low doses of cadmium (Cd) or arsenic (As).

Cadmium experiment: The pigs $(\mathrm{n}=4)$ were given daily $10 \mathrm{mg} \mathrm{Cd}\left(\mathrm{Cd}\right.$ as $\left.\mathrm{CdSO}_{4}\right) / \mathrm{kg}$ body weight in food within the interval of 35 to 239 days after birth followed with $20 \mathrm{mg} \mathrm{Cd} / \mathrm{kg}$ body weight untill day 443. Arsenic experiment: The pigs $(\mathrm{n}=3)$ were given daily $10 \mathrm{mg} \mathrm{As}_{2} \mathrm{O}_{3} / \mathrm{kg}$ body weight in food within interval 35 to 186 days followed by $20 \mathrm{mg} \mathrm{As}_{2} \mathrm{O}_{3} / \mathrm{kg}$ body weight within 64 days. The data of experimental and control $(n=3)$ tissues (myocardial atrium, diaphragm, kidney, liver, lung, spleen, skeletal muscle) were evaluated using the sum of vectors method (SV).

Cadmium experiment: Significant differences $(P<0.05)$ were found in lung, diaphragm, spleen and liver. The relative order of differences between experimental and control tissues (lung < diaphragm $<$ spleen $<$ liver) indicates different sensitivity of these tissues to damage.

Arsenic experiment: Significantly different LD pattern $(P<0.05)$ was only found in liver.

Our data indicate that pig tissues differ in sensitivity to chronic low-level Cd or As load. The liver was found to be the most sensitive among pig tissues to both elements. A study of tissue LD pattern may be complementary to functional tests of organs.

Arsenic, cadmium, chronic subtoxic dose, L-lactate dehydrogenase isoenzyme, liver, lung, diaphragm, spleen

Compounds with arsenic (As) or cadmium (Cd) belong to the group of well-known carcinogens (Chan 1997; Huff 1998). Substances of metalloid As can uncouple mitochondrial oxidative phosphorylation (arsenate substitute phosphate), inhibit glycolytic phosporylation (arsenate replace phosphate), interact with receptors (arsenite inhibit glucocorticoid receptor-mediated transcription) and can bind to sulfhydryl groups of proteins (the inhibition of citric cycle enzymes) (Chan 1997; DeSesso 1998; Kaltreider 2001). Oxidative stress has been recognized as a major mechanism of Cd-induced toxicity (Nigam 1999; Shaikh 1999). Exposure to Cd results in renal, hepatic, pulmonary, gastric, bone and testicular damage (Corpas 1998; Mitsumori 1998; Nigam 1999; Shaikh 1999; Alfvén 2000; A sar 2000). Long-term administration of $1 \mathrm{mg} \mathrm{Cd} / \mathrm{kg}$ body weight (b.w.) daily results in its accumulation in tissues of gilts and cows (Vitásek 2000). The influence on bovine and porcine sexual functions and quality of gametes at the same dose of Cd is reported (Zajíc 2000). Long-term administration of $1 \mathrm{mg} \mathrm{Cd} / \mathrm{kg}$ b.w. daily results in partly decreased resistance of pig spermatozoites, differences in concentration of semen fructose and citric acid with no observable impact on fertility. However, at the same $\mathrm{Cd}$ load, no changes in the rate of ovulation of gilts, fertility of oocytes and early embryo development were found (Jan 1998).

Lactate dehydrogenase (LD, L-lactate:NAD oxidoreductase, EC 1.1.1.27) consists of five tetrameric LD isoenzymes: LD1 $\left(\mathrm{H}_{4}\right), \mathrm{LD} 2\left(\mathrm{HM}_{3}\right), \mathrm{LD} 3\left(\mathrm{H}_{2} \mathrm{M}_{2}\right), \mathrm{LD} 4\left(\mathrm{H}_{3} \mathrm{M}\right)$ and LD5 $\left(\mathrm{M}_{4}\right)$. It is known that LD pattern is tissue specific. Though LD isoenzymes in tissues are sometimes used as diagnostic aid in some studies, they have not been sufficiently explored

Address for correspondence:

RNDr.Jan Šalplachta Ph.D., Department of Biochemistry and Biophysics

Faculty of Veterinary Hygiene and Ecology

maceutical Sciences
Phone:+420 541562510

Fax: +420549243020

http://www.vfu.cz/acta-vet/actavet.htm 
in experiments with $\mathrm{Cd}$ or As as yet. In this study, LD isoenzyms were used as biochemical markers of changes in pig tissues as consequence of long-term, low-level exposure to $\mathrm{Cd}$ or As. Our goal was to find which of the analysed tissues are sensitive to Cd or As.

\section{Materials and Methods}

The animals were conventionally reared on the Clinic of Obstetrics and Gynecology, University of Veterinary and Pharmaceutical Sciences Brno. The project was authorized and monitored by the local University Ethical Commitee.

Cadmium experiment: A healthy Large White pregnant sow was given in food $1 \mathrm{mg} \mathrm{Cd} / \mathrm{kg} \mathrm{b} . \mathrm{w}$. daily. After farrowing, each of 4 littermates (males) was given in food $10 \mathrm{mg} \mathrm{Cd} / \mathrm{kg} \mathrm{b}$.w. daily from day 35 to 239 after birth followed with $20 \mathrm{mg} \mathrm{Cd} / \mathrm{kg}$ b.w. daily until day 443. Cd was administered as $\mathrm{CdSO}_{4}$.

Arsenic experiment: Trial boars $(\mathrm{n}=3)$ were given $10 \mathrm{mg} \mathrm{As} \mathrm{O}_{3} / \mathrm{kg}$ b.w. in food within interval 35 to 186 days followed by $20 \mathrm{mg} \mathrm{As}{ }_{2} \mathrm{O}_{3} / \mathrm{kg}$ b.w. within 64 days until the end of experiment.

Control boars $(n=3)$ were kept and fed (no extra $\mathrm{Cd}$ or As in food) under the same conditions as the pigs of trial groups and were 331-day-old at the end of the experiment. The pigs (Large White) of trial and control groups were littermates of a healthy sow.

Tissue samples were taken immediately after slaughter and stored in liquid nitrogen pending analysis. LD pattern in tissue extract was determined by conventional polyacrylamide gel electrophoresis ( $\breve{S}$ alplachta 2000). LD patterns were converted to the resultant vectors of basic model SV 5,LD(1-5) under conditions stated in (Š alplachta $1997 \mathrm{ab})$. The basic model SV5,LD(1-5) uses a two-dimensional system of rectangular axes $x, y$ in the plane in which LD isoenzymes are represented with constituent vectors starting in the point of intersection of axes. By summation of all constituent vectors every resultant vector is determined so that an end point of resultant vector represents its LD pattern. The end point variables SV5 $[x ; y]$ of resultant vector were used to create the graphical presentation of the results and for statistic evaluation through two-tailed F-test and Student's $t$-test.

Table 1

Mean L-lactate dehydrogenase pattern in tissues of intact pigs and pigs exposed to chronic low-level load of cadmium or arsenic

\begin{tabular}{|l|c|c|c|c|c|c|c|}
\hline Sample & LD $1 \pm \mathrm{s}$ & LD 2 $\pm \mathrm{s}$ & LD $3 \pm \mathrm{s}$ & LD $4 \pm \mathrm{s}$ & LD 5 $\pm \mathrm{s}$ & $\mathrm{SV}[\mathrm{x}] \pm \mathrm{s}$ & $\mathrm{SV}[\mathrm{y}] \pm \mathrm{s}$ \\
\hline ATRIUM & $86.2 \pm 7.0$ & $8.5 \pm 4.6$ & $5.3 \pm 2.7$ & 0 & 0 & $61.8 \pm 9.6$ & $58.7 \pm 0.9$ \\
atrium Cd & $83.6 \pm 3.1$ & $9.3 \pm 2.1$ & $7.0 \pm 1.1$ & 0 & 0 & $57.7 \pm 4.1$ & $58.0 \pm 0.3$ \\
atrium As & $81.3 \pm 1.0$ & $10.9 \pm 0.1$ & $7.8 \pm 0.9$ & 0 & 0 & $54.6 \pm 1.7$ & $58.1 \pm 0.5$ \\
\hline KIDNEY-c & $51.0 \pm 3.0$ & $36.6 \pm 2.2$ & $12.4 \pm 1.0$ & 0 & 0 & $17.6 \pm 4.0$ & $64.7 \pm 0.5$ \\
kidney Cd & $49.2 \pm 4.5$ & $28.9 \pm 2.0$ & $16.8 \pm 1.1$ & $1.7 \pm 2.9$ & $3.4 \pm 3.4$ & $16.3 \pm 2.3$ & $52.8 \pm 9.2$ \\
kidney As & $50.5 \pm 4.8$ & $36.8 \pm 1.0$ & $12.2 \pm 3.4$ & $0.4 \pm 0.06$ & 0 & $17.2 \pm 7.7$ & $64.3 \pm 2.3$ \\
\hline SPLEEN-c & $9.3 \pm 2.5$ & $15.5 \pm 0.7$ & $41.9 \pm 2.5$ & $26.5 \pm 1.1$ & $6.7 \pm 3.4$ & $-41.9 \pm 3.5$ & $-9.0 \pm 4.1$ \\
spleen Cd & $7.9 \pm 1.6$ & $14.3 \pm 0.3$ & $34.1 \pm 0.8$ & $24.0 \pm 1.0$ & $19.7 \pm 2.0$ & $-23.6 \pm 1.1$ & $-16.2 \pm 1.3$ \\
spleen As & $8.1 \pm 0.7$ & $17.5 \pm 0.6$ & $41.7 \pm 1.7$ & $26.9 \pm 0.5$ & $5.8 \pm 1.3$ & $-44.2 \pm 3.2$ & $-7.6 \pm 0.4$ \\
\hline LUNG-c & $15.2 \pm 4.3$ & $20.3 \pm 1.5$ & $31.8 \pm 1.8$ & $20.0 \pm 3.8$ & $12.8 \pm 3.0$ & $-21.6 \pm 1.3$ & $1.7 \pm 8.3$ \\
lung Cd & $16.5 \pm 2.0$ & $20.0 \pm 2.1$ & $30.5 \pm 0.5$ & $17.7 \pm 1.7$ & $15.2 \pm 3.6$ & $-16.5 \pm 2.5$ & $2.9 \pm 6.2$ \\
lung As & $19.4 \pm 3.7$ & $19.9 \pm 1.6$ & $29.4 \pm 2.1$ & $21.9 \pm 1.3$ & $9.4 \pm 2.9$ & $-19.1 \pm 5.9$ & $4.0 \pm 4.0$ \\
\hline LIVER-c & $20.6 \pm 2.3$ & $36.3 \pm 3.3$ & $29.5 \pm 1.5$ & $9.2 \pm 1.5$ & $4.4 \pm 1.7$ & $-23.4 \pm 5.1$ & $35.3 \pm 4.2$ \\
liver Cd & $5.6 \pm 1.1$ & $17.7 \pm 3.5$ & $35.1 \pm 4.5$ & $14.8 \pm 2.7$ & $26.8 \pm 8.6$ & $-18.8 \pm 11.6$ & $-9.7 \pm 9.0$ \\
liver As & $12.4 \pm 3.2$ & $28.8 \pm 4.4$ & $38.7 \pm 1.7$ & $13.5 \pm 3.7$ & $6.5 \pm 2.1$ & $-36.5 \pm 3.1$ & $18.0 \pm 10.1$ \\
\hline DIAPHRAGM-c & $3.9 \pm 0.1$ & $5.1 \pm 0.5$ & $8.8 \pm 0.9$ & $10.4 \pm 1.7$ & $71.8 \pm 2.1$ & $47.7 \pm 3.1$ & $-45.0 \pm 1.3$ \\
diaphragm Cd & $8.2 \pm 1.3$ & $7.6 \pm 2.4$ & $11.0 \pm 1.4$ & $10.1 \pm 1.4$ & $63.1 \pm 4.7$ & $41.1 \pm 6.2$ & $-34.7 \pm 4.5$ \\
diaphragm As & $3.1 \pm 1.2$ & $3.5 \pm 0.8$ & $8.9 \pm 1.9$ & $11.1 \pm 1.8$ & $73.5 \pm 5.5$ & $48.6 \pm 6.3$ & $-48.6 \pm 2.9$ \\
\hline MUSCLE-c & 0 & 0 & $1.7 \pm 1.4$ & $2.0 \pm 1.4$ & $96.3 \pm 2.6$ & $75.6 \pm 3.8$ & $-58.5 \pm 0.5$ \\
muscle Cd & 0 & $0.1 \pm 0.2$ & $4.1 \pm 1.9$ & $5.1 \pm 1.8$ & $90.7 \pm 3.8$ & $67.6 \pm 5.5$ & $-58.0 \pm 0.8$ \\
muscle As & 0 & 0 & $2.8 \pm 1.3$ & $3.7 \pm 0.9$ & $93.5 \pm 2.1$ & $71.7 \pm 3.2$ & $-58.5 \pm 0.5$ \\
\hline
\end{tabular}

Cd: Mean data of 4 boars exposed to $10 \mathrm{mg} \mathrm{CD} / \mathrm{kg}$ (b.w.) daily within interval 35 to 239 days followed by $20 \mathrm{mg}$ $\mathrm{Cd} / \mathrm{kg}$ b.w. until day 443. Cd was administered as $\mathrm{CdSO}_{4}$

As: The mean data of 3 boars exposed to $10 \mathrm{mg} \mathrm{As}_{2} \mathrm{O}_{3} / \mathrm{kg}$ (b.w.) within interval 35 to 186 days, followed by $20 \mathrm{mg}$ $\mathrm{As}_{2} \mathrm{O}_{3} / \mathrm{kg}$ b.w. daily within 64 days until the end of experiment.

CONTROL-c represents mean data of 3 intact boars reared under the same conditions. Relative LD isoenzyme activity is presented. End point of resultant vector is specified co'ordinate variables SV[x], SV[y] of basic model SV5, $\mathrm{LD}(1-5) \mathrm{s}=$ standard deviation 


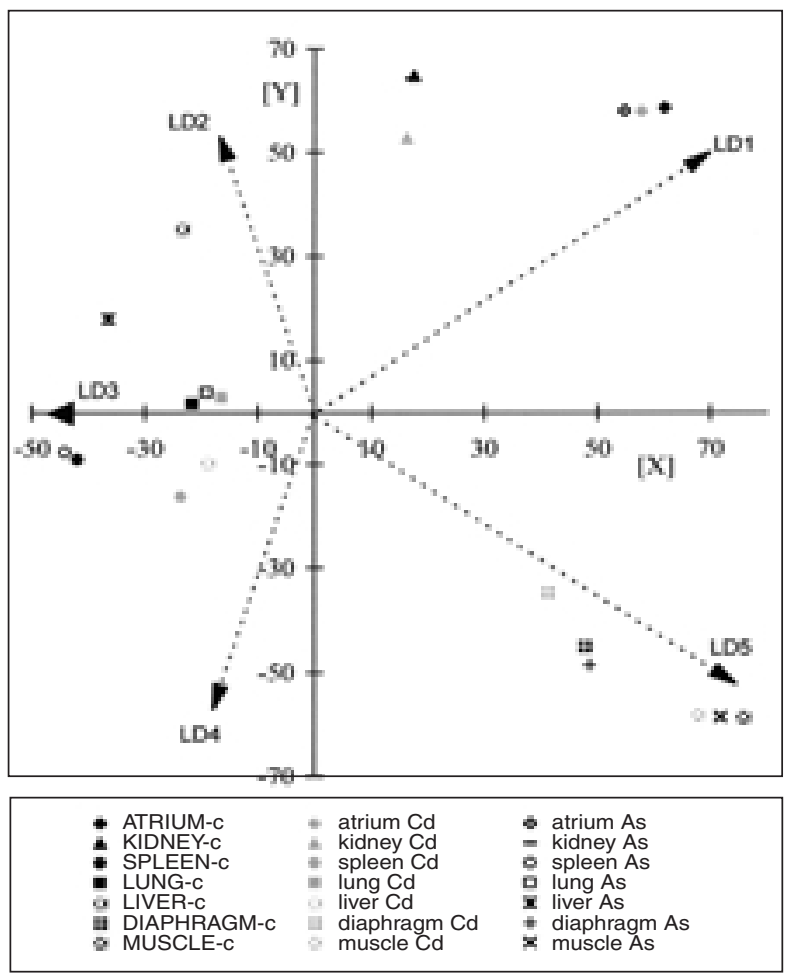

Fig.1. An end point of resultant vector in basic model SV5,LD(1-5) represents mean L-lactate dehydrogenase pattern in tissues of intact pig or pig exposed to chronic low-level cadmium or arsenic.

\section{Results}

\section{Cadmium experiment}

Mean isoenzyme LD patterns of pig tissues are presented in Table 1 and their resultant vectors are depicted in Fig. 1 to illustrate the distribution of LD patterns. There is a clear decrease of LD1 (-15\%), LD2 (-18.6\%) activity and corresponding increase of LD3 (+5.6\%), LD4 (+5.6), LD5 $(+22.4 \%)$ activity in liver of trial pigs. The decrease of LD3 activity $(-7.8 \%)$ and the increase of LD5 activity $(+13 \%)$ in spleen were found, while the increase of LD1 $(+4.3 \%)$ and the decrease of LD5 (-8.7\%) activity in diaphragm of trial pigs were found. A difference of LD isoenzyme activity was within interval $\pm 3 \%$ in lung of trial and control pigs.

Based on two-tailed t-test $(P<0.05)$ of resultant vectors, we state that there is insufficient evidence to conclude that the means of LD patterns are not the same in tissues: atrium, kidney and skeletal muscle. It can be stated that significant differences $(P<0.05)$ between LD patterns of trial and control groups were found in the following tissues: liver, lung, spleen, and diaphragm.

The relative order of the differences between LD patterns trial and controls follows: lung $<$ diaphragm $<$ spleen $<$ liver.

Arsenic experiment

Mean isoenzyme LD pattern of pig tissues are presented in Table 1 and their resultant vectors are shown in Fig. 1. The decrease of LD1 (-8.2\%), LD2 (-7.5\%) and the increase of LD3 $(+9.2 \%)$, LD4 $(+4.3 \%)$, activities were determined in liver of trial group. 
Based on two-tailed $t$-test $(P<0.05)$, we state that there is insufficient evidence to conclude that the means of LD patterns are not the same in the following tissues: atrium, kidney, spleen, lung, diaphragm and skeletal muscle. Significant difference $(P<0.05)$ between LD isoenzyme patterns of trial and control groups was only found in liver tissue.

The results of tissue LD patterns indicate the liver to be the most sensitive organ to chronic low-level administration of cadmium or arsenic.

\section{Discussion}

It is known that a change of LD pattern develops as a consequence of pathological process, e.g. characteristic LD pattern alterations in the brain regions are induced by insecticides carbofuran and methyl parathion (Gupta 2000). In this feeding Cd/As study, we attempted to use LD isoenzymes as biochemical marker of tissue damage. With respect to ethics of animal experimentation, a small number of animals were available for this preliminary long-lasting study and this affects validity of statistic results. We stated that LD patterns were altered in some pig tissues of trial groups in our experiments. Significant diferences $(P<0.05)$ between LD patterns were found in tissues of pigs used in the $\mathrm{Cd}$ experiment: lung, diaphragm, spleen, liver and no changes were found in atrium, kidney and skeletal muscle. We suppose that the relative order of differences between LD patterns of experimental and control tissues (lung $<$ diaphragm $<$ spleen $<$ liver) represents the different sensitivity of these tissues to damage at the reported $\mathrm{Cd}$ consumption. Damage to kidney was not detected. This may appear contradictory to the following data: (Shaikh 1999) reported that the elevated total LD activity and protein found in rat serum and urine as well as the elevation of serum alanin amino transferase originate from liver and kidney damage by chronic $\mathrm{Cd}$ exposure. Hepato-renal toxicity and $\mathrm{Cd}$ accumulation in rats were examined in a feeding study (Mitsumori 1998) at concentrations of 8,40,200, and $600 \mathrm{ppm} \mathrm{Cd}$ for 2, 4 and 8 month from week 5 of age. Hepato-renal damage was apparent in rats exposed to $\geq 200 \mathrm{ppm} \mathrm{Cd}$ after 2 months of exposure. On the other hand, no renal damage was found in rats fed 8 or $40 \mathrm{ppm}$ Cd after 8 months even though the accumulation of $\mathrm{Cd}$ was $91-183$ mikrog $\mathrm{Cd} / \mathrm{g}$ in kidney. Alfvén (2000) proved the dose-relation between Cd intake and prevalence of renal tubular damage by measurements of alfa $^{1}$-microglobulin and $\mathrm{Cd}$ in urine. The foregoing findings suggest that an explanation may lie in different dose and/or medication of cadmium and the species of animal under study.

Our data indicate that liver was the only organ affected by arsenic in contrast to other tissues as found by comparison of LD pattern in tissues between trial and control groups. It seems likely that sensitivity to damage by arsenite is tissue- and dose-specific. This is consistent with dose- and time-dependent survival in arsenic-treated leukemia cell lines (Lu 1999) and data summarised in (Can 1997; DeSesso 1998). Arsenite-induced cell death and cell proliferation display concentration dependence in porcine aortic endothelial cells at concentrations (arsenite $>5 \mu \mathrm{mol} / \mathrm{l})$ and $(5>$ arsenite $>1 \mu \mathrm{mol} / \mathrm{l})$, respectively (Barchowsky 1999).

Arsenic and cadmium are distributed in the enviroment and exposure to them cause health problems. Identification of sensitive tissues is worthwhile not only with possible medication of arsenic trioxide to treat acute promyelocytic leukemia (Lu 1999) but also with increasing As and $\mathrm{Cd}$ pollution of enviroment from anthropogenic sources. Presented data indicate different sensitivities of pig tissues to $\mathrm{Cd}$ or As chronic subtoxic exposure with the liver being the most sensitive from all tested tissues. We therefore suggest to study tissue LD pattern since it may be of advantage and complementary to functional organs tests. 


\section{Isoenzymové složení L-laktátdehydrogenasy ve tkáních kanců vystavených zátěži kadmiem a arsenem}

Sledovali jsme složení L-laktátdehydrogenasy (LD) ve tkáních kanců (bílé ušlechtilé) vystavených chronické subtoxické zátěži kadmiem a arsenem. Pokus s kadmiem: V experimentální skupině byl denní př́ijem kadmia kancem $10 \mathrm{mg} \mathrm{Cd}\left(\mathrm{Cd}\right.$ formou $\left.\mathrm{CdSO}_{4}\right) / \mathrm{kg}$ živé hmotnosti v intervalu 35-239 den po narození se zvýšením na $20 \mathrm{mg} \mathrm{Cd} / \mathrm{kg}$ ž.h. až do ukončení pokusu (443 den). Pokus s arsenem: Denní přijem arsenu kancem byl $10 \mathrm{mg}$ $\mathrm{As}_{2} \mathrm{O}_{3} / \mathrm{kg}$ ž.h. v intervalu 35-186 den se zvýšením na $20 \mathrm{mg} \mathrm{As}_{2} \mathrm{O}_{3} / \mathrm{kg}$ ž.h. během následujících 64 dnů. Složení LD tkání experimentálních a kontrolních zvířat atrium, bránice, ledvina, játra, plíce, slezina a kosterní sval bylo vyhodnoceno pomocí metody součtu vektorů (SV).

Pokus s kadmiem: Statisticky významný rozdíl $(P<0,05)$ byl zjištěn u tkání: plíce, bránice, slezina a játra. Relativní pořadí rozdílů mezi experimentální a kontrolní skupinou (plíce < bránice < slezina < játra) naznačuje rozdílnou citlivost tkání k zátěži kadmiem.

Pokus s arsenem: Statisticky významný rozdíl $(P<0,05)$ byl zjištěn pouze u jater. Výsledky naznačují rozdílnou citlivost tkání při chronické subtoxické zátěži kadmiem a arsenem, přičemž se játra jeví jako nejcitlivějši. Stanovení isoenzymů LD může být vhodné jako doplněk funkčních testů orgánů.

Acknowledgements

We are grateful to Prof. MVDr. Eduard Kudláč DrSc. (University of Veterinary and Pharmaceutical Sciences, Brno) for the gift of tissue samples.

\section{References}

ALFVÉN, T., ElindER, C-G., CARLSSON, M.D., GRUBB, A., HELlSTRÖM, L., PERSSON, B., PETTERSSON, C., SPǍNG, G., SCHÜTZ, A., JÄRUP, L. 2000: Low-level cadmium exposure and osteoporosis. J.Bone Miner. Res. 15: 1579-1586

ASAR, M., KAYISLI, Ü.A., IZGÜT-UYSAL, V.N., ÖNER ,G., POLAT, S., KAYA, M. 2000: Cadmium-induced changes in parietal cell structure and functions of rats. Biol.Trace Element Res. 74: 153-170

BARCHOWSKY, A., ROUSSEL, R.R., KLEI, L.R., JAMES, P.E., GANJU, N., SMITH, K.R., DUDEK, E.J. 1999: Low levels of arsenic trioxide stimulate proliferative signals in primary vascular cells without activating stress effector pathways. Toxicol. Appl. Pharmacol. 159: 65-75

CORPAS, I., ANTONIO, M.T. 1998: Study of alterations produced by cadmium and cadmium/lead administration during gestational and early lactation periods in the reproductive organs of the rat. Ecotoxicol. Environ. Saf. 41: $180-188$

DeSESSO, J.M., JACOBSON, C.F., SCIALLI, A.R., FARR, C.H., HOLSON, J.F. 1998: An assessment of the developmental toxicology of inorganic arsenic. Reprod.Toxicol. 12: 385-433

GUPTA, R.C., GOAD, J.T., MILATOVIC, D., DETTBARN, W-D. 2000: Cholinergic and noncholinergic brain biomarkers of insecticide exposure and effects. Hum.Exp.Toxicol. 19: 297-308

HUFF, J.E. 1998: NTP report on carcinogens: history, concepts, procedures, processes. Eur. J. Oncol. 3: 343-355

CHAN, P.C., HUFF, J. 1997: Arsenic carcinogenesis in animals and humans: Mechanistics, experimental, and epidemiological evidence. Environ. Carcino. \& Ecotox. Revs. C15: 83-122

JAN, Z., DOLEŽAL, R., KUDLÁČ, E., LOPATÁŘOVÁ, M., VINKLER, R., ZAJíC, J. 1998: Influence of cadmium on gametes and early embryos of pigs in vivo and in vitro. Vet. Med. - Czech 43: 287

KALTREIDER, R.C., DAVIS, A.M., LARIVIERE, J.P., HAMILTON J.W. 2001: Arsenic alters the function of the glucocorticoid receptor as a transcription factor. Environ. Health Perspect. 109: 245-251

LU, M., LEVIN, J., SULPICE, E., SEQUEIRA-Le GRAND, A., ALEMANY, M., CAEN, J.P., HAN, Z.Ch. 1999: Effect of arsenic trioxide on viability, proliferation, and apoptosis in human megakaryocytic leukemia cell lines. Exp. Hematol. 27: 845-52

MITSUMORI, K., SHIBUTANI, M., SATO, S., ONODERA, H., NAKAGAWA, J., HAYASHI, Y., ANDO, M. 1998: Relationship between the development of hepato-renal toxicity and cadmium accumulation in rats given minimum to large amounts of cadmium chloride in the long-term: preliminary study. Arch.Toxicol. 72: 545-552

NIGAM, D., SHUKLA G.S., AGARWAL A.K. 1999: Glutathione depletion and oxidative damage in mitochondria followingg exposure to cadmium in rat liver and kidney. Toxicology Letters 106: 151-157

SHAIKH, Z.A., VU, T.T., ZAMAN, K. 1999: Oxidative stress as a mechanism of chronic cadmium-induced hepatotoxicity and renal toxicity and protection by antioxidants. Toxicol. Appl. Pharmacol. 154: 256-263

ŠALPLACHTA, J. 1997: Metoda součtu vektorů (SV) a její aplikace na isoenzymy laktátdehydrogenasy a 
kreatinkinasy. (The method of summation of vectors (SV) and its application to lactate dehydrogenase and creatine kinase isoenzymes) Ph.D.Thesis, Univ.Vet.Pharm.Sci., Brno $114 \mathrm{p}$.

ŠALPLACHTA, J. 1997: The sum of vectors method (SV) applied to the lactate dehydrogenase isoenzymes and the creatine kinase isoforms. Clin. Chim. Acta 259: 51-71

ŠALPLACHTA, J., NEČAS, J. 2000: Lactate dehydrogenase isoenzyme pattern in calf tissues and serum. Acta Vet. Brno 69: 267-275

VITÁSEK, R. 2000: Vliv kadmia na peripartální období u krav a prasnic. (The influence of cadmium on peripartal period of cows and sows.) PhD. Thesis, Univ. Vet. Pharm. Sci., Brno, 108 p.

ZAJÍC, J. 2000: Vliv kadmia na pohlavní funkce a kvalitu gamet skotu a prasat. (The influence of cadmium on bovine and porcine sexual function and quality of their gamets.) PhD. Thesis, Univ. Vet. Pharm. Sci., Brno, 129 p. 